\title{
Community-level carbon flux variability over a tidal cycle in Zostera marina and $Z$. noltii beds
}

\author{
Vincent Ouisse $^{1,2, *}$, Aline Migné ${ }^{1,2}$, Dominique Davoult ${ }^{1,2}$ \\ ${ }^{1}$ UPMC Univ Paris 06, UMR7144, Roscoff, France \\ ${ }^{2}$ CNRS, UMR 7144, Equipe Réseaux Trophiques et Production Benthique, Station Biologique, Place Georges Teissier, BP 74, \\ 29682, Roscoff Cedex, France
}

\begin{abstract}
Abiotic parameters such as light, temperature, nutrient availability and inorganic carbon source are known to vary widely between immersion and emersion. We measured gross community productivity (GCP) and community respiration (CR) over spring tidal cycles in intertidal Zostera marina and $Z$. noltii communities. $\mathrm{CO}_{2}$ fluxes during emersion and inorganic carbon fluxes during immersion were assessed using closed benthic chambers. GCP and CR rates were significantly higher during immersion than during emersion for both communities. In July, GCP rates were 3- and 5-fold higher and CR rates were 2.5- and 9-fold higher during immersion for the $Z$. marina and Z. noltii communities, respectively. This trend was confirmed in the $Z$. noltii community at different periods of the year (February, April and November). Neither photoinhibition nor desiccation was measured during emersion, but shading might have greatly limited the GCP rates. Higher CR during immersion could be explained by enhanced bacterial and infaunal activity.
\end{abstract}

KEY WORDS: Production $\cdot$ Primary productivity $\cdot$ Respiration $\cdot$ Seagrass $\cdot$ Intertidal $\cdot$ Temporal variability $\cdot$ Metabolism

Resale or republication not permitted without written consent of the publisher

\section{INTRODUCTION}

In temperate areas, research has emphasised the pronounced influence of temperature, light, inorganic carbon and nutrient availability on both leaf photosynthesis and community metabolism in seagrasses (see Lee et al. 2007 for review). However, little attention has been given to the response of intertidal seagrasses to these parameters when exposed to air. It is known that abiotic parameters such as temperature, light and nutrients vary greatly between immersion and emersion, creating important modifications to the plants' environment. During emersion, light intensity is always higher than during immersion. Temperature can also be higher, while nutrient availability sources are reduced to pore water in sediment. Intertidal seagrasses are also exposed to varying concentrations of inorganic carbon such as gaseous $\mathrm{CO}_{2}$ during emersion and dissolved $\mathrm{CO}_{2}$, bicarbonate $\left(\mathrm{HCO}_{3}^{-}\right)$and carbonate $\left(\mathrm{CO}_{3}{ }^{2-}\right)$ during immersion.
Zostera marina and Z. noltii, temperate seagrasses that inhabit the low intertidal zone, can be exposed to air for several hours, particularly during spring tides. Several studies have highlighted the important effect of light on primary production of $Z$. marina (e.g. Drew 1979, Mazzella \& Alberte 1986) and $Z$. noltii (e.g. Jiménez et al. 1987) during immersion. Desiccation tolerance has been studied in both species at the scale of leaves using pulse-amplitude modulation (PAM) methods (Shafer et al. 2007) or $\mathrm{CO}_{2}$ gas analysers (Leuschner \& Rees 1993, Leuschner et al. 1998). Over the course of a tidal cycle, Silva et al. (2005) measured a lower photosynthetic response during immersion than emersion using PAM methods and explained this result by the rapid air-water $\mathrm{CO}_{2}$ diffusion in the thin water film on leaves exposed to the air. However, these measurements were conducted only on leaves and overlooked interactions at the community scale. Seagrasses are just one component of a highly diverse 
system that also includes significant biomass contributions from other primary producers such as benthic microalgae, macroalgae and epiphytes (McRoy \& McMillan 1977), which create large interspecific interactions.

Some measurements have been performed at the community scale in Zostera marina beds under immersion (Martin et al. 2005) and in $Z$. noltii beds under both immersion (Plus et al. 2001) and emersion (Ouisse et al. 2010). A direct comparison of aerial and underwater carbon metabolism has only been documented on a $Z$. noltii bed in the Banc d'Arguin, Mauritania (Clavier et al. 2011), and investigations at the community scale over tidal cycles are still needed. In this context, the aim of the present study was to measure the variation in community metabolism at the scale of a tidal cycle in $Z$. marina and $Z$. noltii beds .

\section{MATERIALS AND METHODS}

\section{Study site}

This study was carried out on 2 intertidal seagrass communities near Roscoff (western English Channel, France), where the maximal tidal amplitude is approximately $9 \mathrm{~m}$. The Zostera marina $\left(48^{\circ} 44.299 \mathrm{~N}\right.$, $\left.3^{\circ} 58.390 \mathrm{~W}\right)$ and $Z$. noltii beds $\left(48^{\circ} 41.735 \mathrm{~N}\right.$, $3^{\circ} 57.653 \mathrm{~W}$ ) are located below 1.8 and $3.3 \mathrm{~m}$ (above chart datum-lowest astronomical tide), respectively. During spring tide, emersion occurs at approximately mid-day and the $Z$. noltii community is exposed to the air for several hours, whereas the $Z$. marina community is exposed for less than $2 \mathrm{~h}$.

\section{In situ measurements of abiotic parameters}

Temperature $\left({ }^{\circ} \mathrm{C}\right)$ and photosynthetically available radiation ( $\mathrm{PAR}_{i} \mu \mathrm{mol}$ quanta $\mathrm{m}^{-2} \mathrm{~s}^{-1}$ ) were measured in air next to the study sites with a Vaisala HMP45C (for temperature) and a Skye SKP215 flat sensor (for ambient light), and were recorded every $15 \mathrm{~min}$ throughout the year. In seawater, temperature, depth and PAR were measured in each Zostera community next to the benthic chamber (approximately $10 \mathrm{~cm}$ above the sediment surface) using ultra-miniature MDS-MKV sensors (Alec Electronics ${ }^{\mathrm{TM}}$ ), and were recorded at $1 \mathrm{~min}$ intervals during carbon flux measurements. A PAR conversion factor $\left(0.571, \mathrm{R}^{2}=0.868, \mathrm{p}<0.001, \mathrm{n}=\right.$ 1769) was estimated from simultaneous flat and spherical sensor measurements in order to convert underwater light to flat surface measurements ( $\mu$ mol quanta $\mathrm{m}^{-2} \mathrm{~s}^{-1}$ ).

\section{Benthic carbon flux measurements}

Benthic chambers (surface area $=0.071 \mathrm{~m}^{2}$ ) were pushed down to $10 \mathrm{~cm}$ sediment depth, sealed with clear (for net community productivity [NCP] measurements) or dark (for community respiration [CR] measurements) acrylic hemispheres to trap a known volume (ca. 11 l, depending on the core insertion into the sediment) of seawater or air (for immersion or emersion, respectively). Gross community productivity (GCP) was then calculated by correcting NCP by CR with the assumption that $\mathrm{CR}$ rates are equivalent under light and dark conditions. During immersion, the seawater inside the chambers was mixed by autonomous stirrers. Seawater was collected from inside the benthic chambers using $100 \mathrm{ml}$ syringes at the beginning and end of incubations (duration of incubations was ca. 40 to $60 \mathrm{~min}$ ) and then passed through cellulose acetate membrane filters $(0.8 \mu \mathrm{m})$ for potentiometric laboratory determination of total alkalinity (Millero et al. 1993), which was performed the following day on 3 subsamples of $20 \mathrm{ml}$. The $\mathrm{pH}$ of seawater samples was measured immediately after sampling. The inorganic carbon concentration of seawater was calculated from the $\mathrm{pH}$, total alkalinity (TA), temperature and salinity according to Strickland \& Parsons (1972) and using the formula given in Oviatt et al. (1986). The inorganic carbon fluxes were then calculated using the difference between the final and initial concentrations and expressed in carbon units for the community (mg C m${ }^{-2} \mathrm{~h}^{-1}$ ). During emersion, inorganic carbon fluxes were measured in the benthic chambers using closed air circuits for $\mathrm{CO}_{2}$ analysis (see Migné et al. 2002 for the method). Changes in air $\mathrm{CO}_{2}$ concentration (ppm) were measured in the chamber with $\mathrm{CO}_{2}$ infrared gas analysers (LiCor Li800). Gas exchange was monitored for 10 to $30 \mathrm{~min}$ to ensure the linearity of the measurements. Data were recorded with data loggers (LiCor Li-1400) at $15 \mathrm{~s}$ intervals. $\mathrm{CO}_{2}$ fluxes were then calculated from the recorded data using the slope of $\mathrm{CO}_{2}$ concentration $\left(\mu \mathrm{mol} \mathrm{mol}{ }^{-1}\right.$ ) against time (min). Results were expressed in carbon units for the bulk benthic community $\left(\mathrm{mg} \mathrm{C} \mathrm{m}^{-2} \mathrm{~h}^{-1}\right)$, assuming a molar volume of $22.4 \mathrm{l}$ at standard temperature and pressure. Carbon fluxes are measured from the community to the environment, and are positive when respiration is greater than carbon fixation and negative when carbon fixation by the community is greater than respiration. 


\section{Sampling procedure}

Carbon fluxes were measured in situ during spring tide cycles in July and October 2009 and February 2010 for the Zostera marina community and in April, July and November 2009 and February 2010 for the $Z$. noltii community. On each occasion, 3 benthic chambers were positioned approximately $2 \mathrm{~m}$ apart to account for spatial variability. Successive underwater incubations (up to 5) were performed at ambient light during ebb tide. When emersion occurred, successive incubations (up to 6) were then performed in air on the same communities, first at ambient light and then in darkness. Finally, 1 dark incubation was performed during immersion on the subsequent rising tide. The benthic chambers were opened for at least $10 \mathrm{~min}$ between successive incubations to restore ambient conditions. For the $Z$. marina community, measurements during both immersion and emersion periods were made only once (on July 24).

To characterise the relationship between photosynthesis (GCP) and light, carbon fluxes were also measured as a function of varying irradiance during air exposure for the Zostera marina community (April and September 2008, March and June 2009 and February 2010), and for the $Z$. noltii community (April, June, August and September 2008, March, June and November 2009 and January 2010). For each date, 1 benthic chamber was covered with a series of neutral density filters under ambient light to create an artificial range of light intensities from maximum ambient daylight to darkness.

After each carbon flux measurement, Zostera spp. leaves and associated epiphytes, benthic macroalgae and 3 sediment cores $(16 \mathrm{~mm}$ inner diameter, $10 \mathrm{~mm}$ depth) for benthic microalgae were collected inside each benthic chamber to determine the biomass of primary producers.

\section{Primary producer biomass}

Chlorophyll a ( $\mathrm{chl} a)$ was extracted from the sediment cores in $90 \%$ acetone, gently mixed, stored at $6^{\circ} \mathrm{C}$ for $4 \mathrm{~h}$ and centrifuged at $4000 \mathrm{rpm}$ for $15 \mathrm{~min}$. Chl a content was determined by spectrophotometry (see Jeffrey \& Humphrey 1975 for the method) and expressed in units per sediment area $\left(\mathrm{mg} \mathrm{chl} a \mathrm{~m}^{-2}\right)$. Finally, the benthic microalgae biomass inside the benthic chamber was expressed as $\mathrm{g} \mathrm{C} \mathrm{m}^{-2}$ using a C:chl a ratio of 40.8 according to de Jonge (1980). Zostera spp. leaves plus associated epiphytes and macroalgae were dried separately at $60^{\circ} \mathrm{C}$ to a constant weight (dry weight, DW), and the carbon portion of the DW was estimated from CHN analysis using a Flash EA CN analyser. Biomass of primary producers was then expressed as $\mathrm{g} \mathrm{C}^{-2}$ using a carbon portion of DW of $43.5 \%$ for $Z$. noltii plus associated epiphytes, $40.1 \%$ for $Z$. marina plus associated epiphytes, $33.7 \%$ for perennial macroalgae (small red algae) and $35.2 \%$ for ephemeral macroalgae (Ulva spp.).

\section{Statistical treatment and analyses}

The highest GCP of each condition was used to compare immersion and emersion rates. Considering the different dates of measurements $(1$ date in Zostera marina and 4 dates in $Z$. noltii beds, 3 benthic chambers at each experiment) as replication, groups of 15 paired (immersion-emersion) observations are available for each process (highest GCP and CR). The normality of these pooled data was verified (Shapiro test, $\mathrm{p}>0.05$ ), and paired $t$-tests were applied to test for differences between immersion and emersion rates.

Photosynthetic parameters of community (maximum GCP, GCP ${ }_{\max }$ and the saturation onset parameter, $I_{k}$ ) during emersion were estimated for each sampling date by fitting GCP and mean recorded PAR during measurements with the mathematical model of Webb et al. (1974):

$$
\mathrm{GCP}=\mathrm{GCP}_{\max }\left[1-\exp ^{\left(-\frac{I}{I_{k}}\right)}\right]
$$

where GCP and $\mathrm{GCP}_{\max }$ are in units of $\mathrm{mg} \mathrm{C} \mathrm{m} \mathrm{m}^{-2} \mathrm{~h}^{-1}$, and $I$ (light intensity) and $I_{k}$ are in units of $\mu \mathrm{mol}$ quanta $\mathrm{m}^{-2} \mathrm{~s}^{-1}$.

$\mathrm{GCP}_{\max }$ and $I_{k}$ were estimated by minimisation of an ordinary least-square criterion performed by a simplex algorithm (Nelder \& Mead 1965). The relationship between photosynthesis (GCP) and light was then tested with an F-test using SPSS Systat $11^{\odot}$ software.

\section{RESULTS}

\section{Underwater versus aerial carbon fluxes}

Carbon fluxes measured over a tidal cycle varied with exposure to air and light. In the Zostera marina community (24 July; Fig. 1a) under the lowest ambi- 


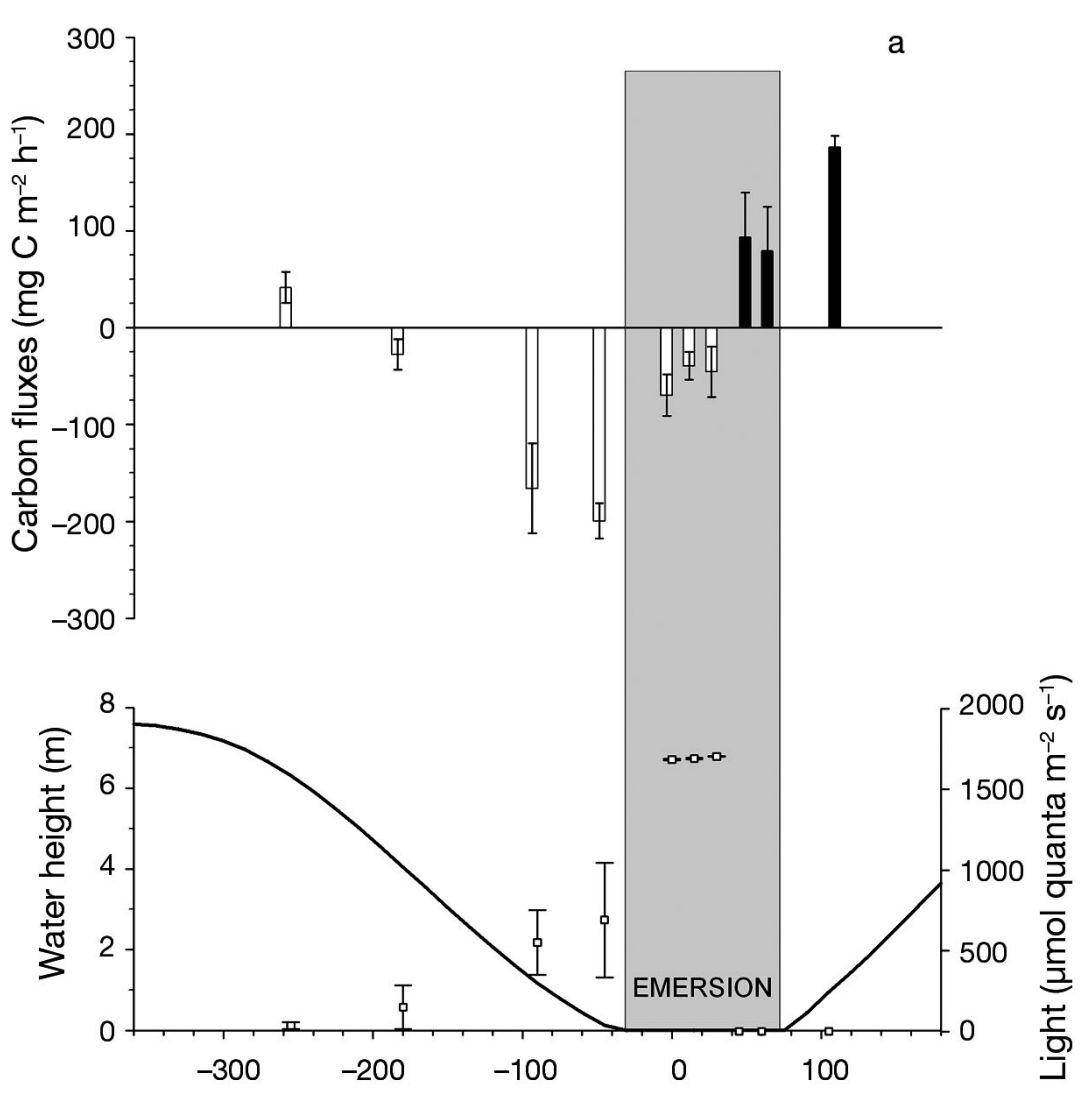

Time before and after low tide ( $\mathrm{min})$

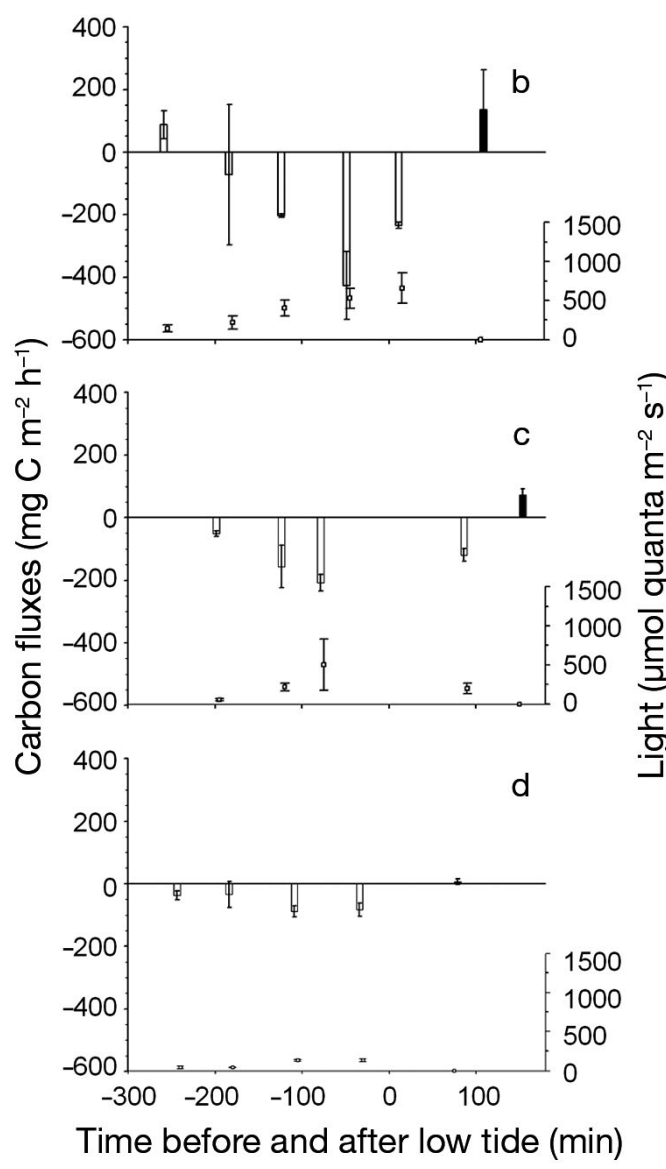

Fig. 1. Mean $( \pm \mathrm{SD})$ carbon flux $\left(\mathrm{mg} \mathrm{C} \mathrm{m}^{-2} \mathrm{~h}^{-1}\right)$, water height (solid line in panel a, $\mathrm{m}$ ) and ambient light (open square, $\mu$ mol quanta $\mathrm{m}^{-2} \mathrm{~s}^{-1}$ ) during light (white bars) and dark (dark bars) incubations in the Zostera marina community over a tidal cycle on (a) 24 July 2009, (b) 9 July 2009, (c) 19 October 2009 and (d) 17 February 2010. The grey shaded area corresponds to the emersed condition (data only available for 24 July 2009)

ent light $\left(38 \pm 22 \mu \mathrm{mol}\right.$ quanta $\left.\mathrm{m}^{-2} \mathrm{~s}^{-1}\right)$, community carbon fluxes were positive $\left(41.54 \pm 16.06 \mathrm{mg} \mathrm{C} \mathrm{m}^{-2}\right.$ $\mathrm{h}^{-1}$ ), which indicated that photosynthesis did not compensate for CR. During the ebb tide, community carbon fluxes increased in absolute value with a maximum just before emersion $(-199.52 \pm 18.16 \mathrm{mg}$ $\left.\mathrm{C} \mathrm{m}^{-2} \mathrm{~h}^{-1}\right)$, corresponding to maximum ambient light in water $\left(690 \pm 356 \mu \mathrm{mol}\right.$ quanta $\left.\mathrm{m}^{-2} \mathrm{~s}^{-1}\right)$. During emersion, ambient light was high $(1684 \pm 5$ to $1706 \pm$ $2 \mu \mathrm{mol}$ quanta $\mathrm{m}^{-2} \mathrm{~s}^{-1}$ ) but community carbon fluxes were smaller $(-39.31 \pm 14.32$ to $-69.68 \pm 21.54 \mathrm{mg} \mathrm{C}$ $\mathrm{m}^{-2} \mathrm{~h}^{-1}$ ) than during immersion. CR was $2.5 \pm 1.6$-fold higher during immersion $\left(186.34 \pm 12.17 \mathrm{mg} \mathrm{C} \mathrm{m}^{-2}\right.$ $\left.\mathrm{h}^{-1}\right)$ than during emersion $(79.14 \pm 45.87$ to $93.36 \pm$ $\left.46.28 \mathrm{mg} \mathrm{C} \mathrm{m}^{-2} \mathrm{~h}^{-1}\right)$ at a similar temperature $\left(17.8^{\circ} \mathrm{C}\right.$ in seawater and $17.2^{\circ} \mathrm{C}$ in air; Table 1). The highest GCP calculated from correcting NCP by $\mathrm{CR}$ was approximately 3 times higher during immersion than during emersion (Fig. 2a, b, respectively).
For the same period, in the Zostera noltii community (27 July; Fig. 3a), carbon fluxes were always negative in daylight and varied during immersion from $-22.14 \pm 13.22$ to $-142.60 \pm 44.19 \mathrm{mg} \mathrm{C} \mathrm{m}^{-2}$ $\mathrm{h}^{-1}$, reaching their maximum (in absolute value) just before emersion when the ambient light was the highest in water $\left(639 \pm 174 \mu \mathrm{mol}\right.$ quanta $\left.\mathrm{m}^{-2} \mathrm{~s}^{-1}\right)$. Community carbon fluxes were smaller during emersion $\left(-23.41 \pm 4.71\right.$ to $\left.-30.42 \pm 0.77 \mathrm{mg} \mathrm{C} \mathrm{m}^{-2} \mathrm{~h}^{-1}\right)$ than during immersion whereas light was higher $(1457 \pm 6$ to $1532 \pm 102 \mu \mathrm{mol}$ quanta $\mathrm{m}^{-2} \mathrm{~s}^{-1}$ ). The $\mathrm{CR}$ was extremely variable among chambers during immersion $\left(109.08 \pm 77.96 \mathrm{mg} \mathrm{C} \mathrm{m}^{-2} \mathrm{~h}^{-1}\right)$, and was more than 9 times higher as compared with emersion $(8.29 \pm 1.25$ to $10.92 \pm 3.52 \mathrm{mg} \mathrm{C} \mathrm{m}^{-2} \mathrm{~h}^{-1}$; Fig. $2 \mathrm{c}, \mathrm{d}$, respectively), although the mean temperature varied only from $17.6^{\circ} \mathrm{C}$ in seawater to $16.6^{\circ} \mathrm{C}$ in air (Table 1). The highest GCP was 5 times higher during immersion than emersion. As observed in July, carbon fluxes in 
Table 1. Mean $( \pm \mathrm{SD})$ primary producer biomass in the benthic chambers $(\mathrm{PPB})$, maximum mean light and temperature during light $\left(T_{\mathrm{NCP}}\right)$ and dark $\left(T_{\mathrm{CR}}\right)$ incubations measured over a tidal cycle in July 2009 (9th and 24th), October 2009 and February 2010 in the Zostera marina community and in April, July and October 2009 and February 2010 in the Zostera noltii community. NCP: net community productivity; CR: community respiration

\begin{tabular}{|c|c|c|c|c|c|c|c|}
\hline \multirow{2}{*}{ Sampling date } & \multirow{2}{*}{$\begin{array}{c}\mathrm{PPB} \\
\left(\mathrm{g} \mathrm{C} \mathrm{m}^{-2}\right)\end{array}$} & \multicolumn{3}{|l|}{ Immersion } & \multicolumn{3}{|l|}{-Emersion } \\
\hline & & $\begin{array}{c}\text { Light } \\
\left(\mu \mathrm{mol} \text { quanta } \mathrm{m}^{-2} \mathrm{~s}^{-1}\right)\end{array}$ & $\begin{array}{l}T_{\mathrm{NCP}} \\
\left({ }^{\circ} \mathrm{C}\right)\end{array}$ & $\begin{array}{l}T_{\mathrm{CR}} \\
\left({ }^{\circ} \mathrm{C}\right)\end{array}$ & $\begin{array}{c}\text { Light } \\
\left(\mu \mathrm{mol} \text { quanta } \mathrm{m}^{-2} \mathrm{~s}^{-1}\right)\end{array}$ & $\begin{array}{l}T_{\mathrm{NCP}} \\
\left({ }^{\circ} \mathrm{C}\right)\end{array}$ & $\begin{array}{l}T_{\mathrm{CR}} \\
\left({ }^{\circ} \mathrm{C}\right)\end{array}$ \\
\hline \multicolumn{8}{|l|}{ Zostera marina } \\
\hline 9 Jul 2009 & $99.7 \pm 25.48$ & $529 \pm 127$ & 15.5 & 16.7 & & & \\
\hline 24 Jul 2009 & $163.08 \pm 46.68$ & $690 \pm 356$ & 17.7 & 17.8 & $1694 \pm 5$ & 17.0 & 17.2 \\
\hline Oct 2009 & $69.91 \pm 26.17$ & $502 \pm 327$ & 15.3 & 15.1 & & & \\
\hline Feb 2010 & $12.74 \pm 2.77$ & $133 \pm 13$ & 8.3 & 8.6 & & & \\
\hline \multicolumn{8}{|l|}{ Zostera noltii } \\
\hline Apr 2009 & $19.42 \pm 8.8$ & $275 \pm 79$ & 12.9 & 14.9 & $1215 \pm 220$ & 17.8 & 18.7 \\
\hline Jul 2009 & $30.24 \pm 16.53$ & $639 \pm 174$ & 17.9 & 17.6 & $1532 \pm 102$ & 16.5 & 16.6 \\
\hline Nov 2009 & $28.49 \pm 7.91$ & $131 \pm 74$ & 12.6 & 13.1 & 829 & 13.1 & 13.2 \\
\hline Feb 2010 & $5.84 \pm 1.98$ & $305 \pm 100$ & 7.4 & 8.8 & $1017 \pm 128$ & 7.5 & 7.9 \\
\hline
\end{tabular}
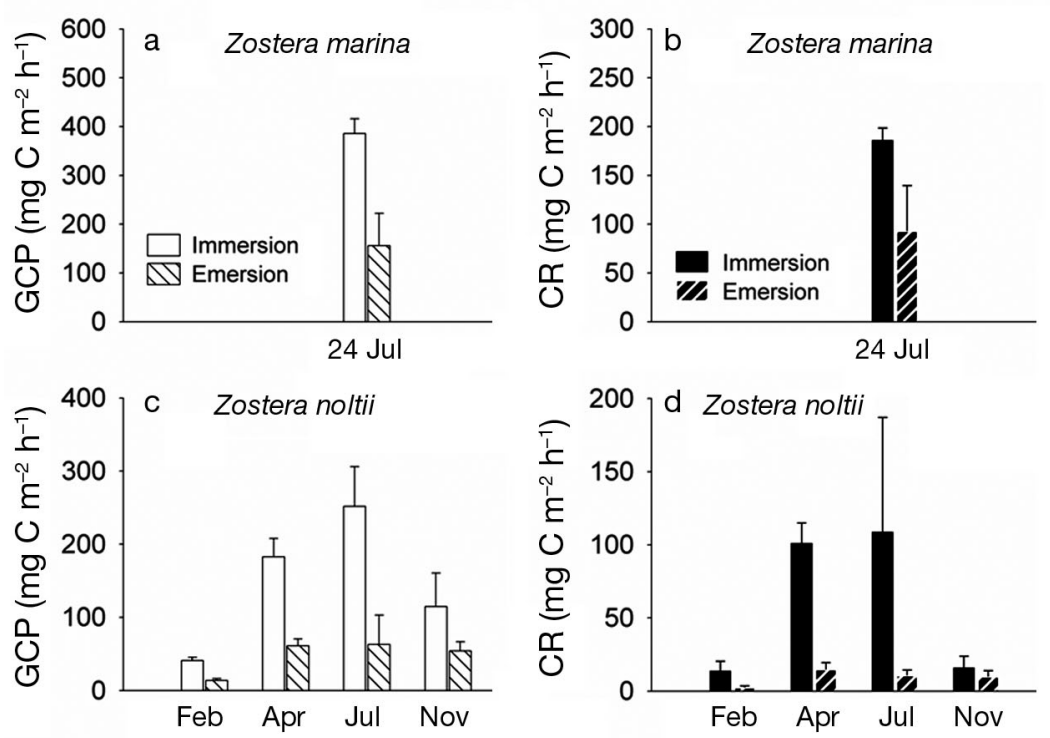

Fig. 2. Mean $( \pm \mathrm{SD})$ highest $(\mathrm{a}, \mathrm{c})$ gross community productivity $(\mathrm{GCP})$ and $(\mathrm{b}, \mathrm{d})$ community respiration (CR) in the Zostera marina community on 24 July 2009 and the Z. noltii community on 27 July 2009, 24 April 2009, 17 November 2009 and 16 February 2010, respectively, during immersion (solid bars) and emersion (hatched bars)

the $Z$. noltii community always reached their maximum during immersion, just before low tide (Fig. 3).

Considering all data (Fig. 2), the highest measured GCP and CR were significantly higher during immersion than during emersion (paired $t$-test on grouped data, GCP, $\mathrm{p}<0.001, \mathrm{n}=15 ; \mathrm{CR}, \mathrm{p}<0.001, \mathrm{n}=15$ ).

\section{Carbon fluxes under immersion over the year}

In the Zostera marina community, the CR and maximal GCP during immersion were lowest in February and highest in July (Fig. 1). Conversely, the ratio between GCP and primary producer biomass (PPB) during immersion was lowest in July $\left(2.51 \pm 0.78 \mathrm{mg} \mathrm{C} \mathrm{g}^{-1} \mathrm{C} \mathrm{h}^{-1}\right)$ and highest in February $\left(7.60 \pm 1.67 \mathrm{mg} \mathrm{C} \mathrm{g}^{-1}\right.$ $\mathrm{C} \mathrm{h}^{-1}$ ). In the $Z$. noltii community, the GCP was lowest in February and high in April, July and November. The GCP:PPB ratio was highest in April $\left(10.43 \pm 3.50 \mathrm{mg} \mathrm{C} \mathrm{g}^{-1} \mathrm{C} \mathrm{h}^{-1}\right)$ and lowest in February $(4.08 \pm 1.14$ mg $\mathrm{C} \mathrm{g}^{-1} \mathrm{C} \mathrm{h}^{-1}$; Fig. 2c). CR also reached its minimum in February and its maximum in July (Fig. 2d).

\section{Carbon fluxes as a function of irradiance under air exposure}

Photosynthetic parameters calculated on additional carbon flux measurements under artificial decreasing light during emersion for both communities also varied over the course of the year. $\mathrm{GCP}_{\max }$ of the Zostera marina community reached its maximum in September 2008 and its minimum in April 2008 (Table 2). In the Z. noltii community, $\mathrm{GCP}_{\max }$ was the lowest in January 2010 and the highest in September 2008 (Table 2). The saturation onset parameter $\left(I_{k}\right)$ was higher in summer (in June 2009 for $Z$. marina and in August 2008 for $Z$. noltii) and lower in March 2009 and in January 2010 for the $Z$. marina and Z. noltii communities, respectively. 


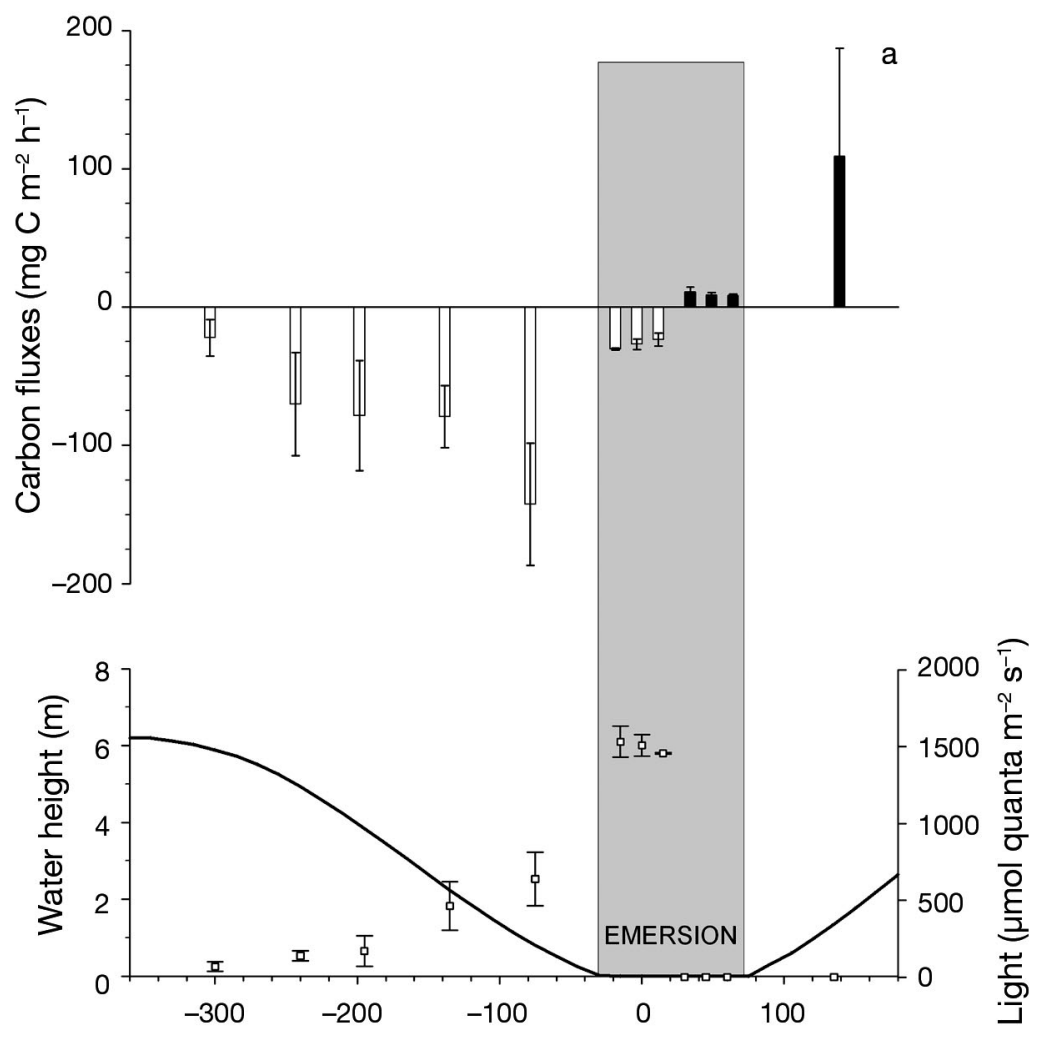

Time before and after low tide ( $\mathrm{min})$

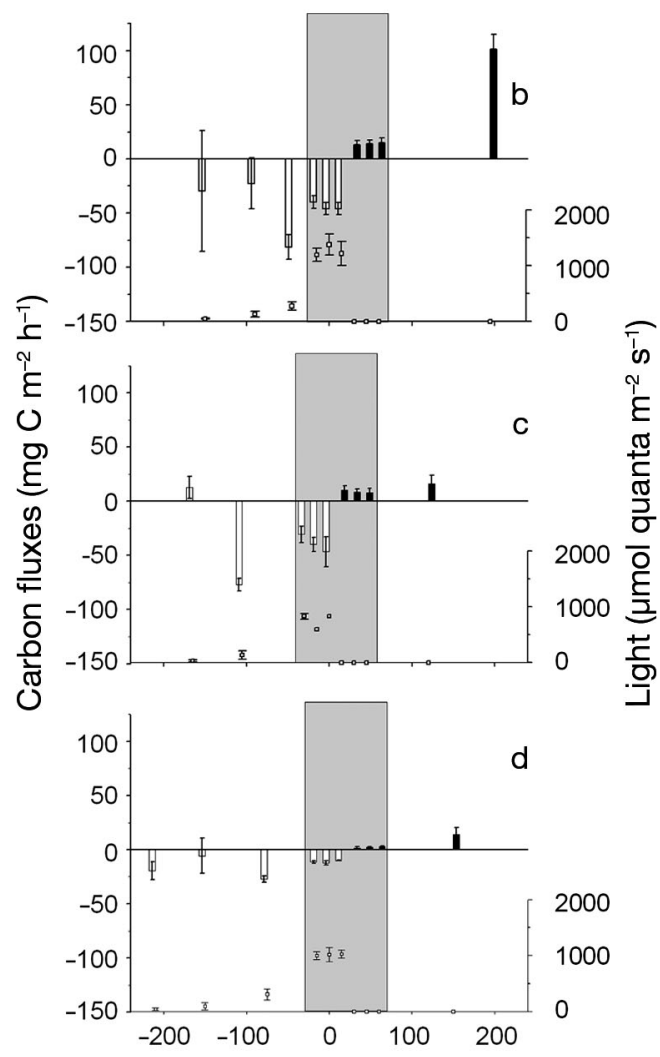

Time before and after low tide ( $\mathrm{min})$

Fig. 3. Mean $\left( \pm \mathrm{SD}\right.$ ) carbon fluxes $\left(\mathrm{mg} \mathrm{C} \mathrm{m}^{-2} \mathrm{~h}^{-1}\right)$, water height (solid line in panel a, $\mathrm{m}$ ) and ambient light (open square, $\mu \mathrm{mol}$ quanta $\mathrm{m}^{-2} \mathrm{~s}^{-1}$ ) during light (white bars) and dark (dark bars) incubations in the Zostera noltii community over a tidal cycle on (a) 27 July 2009, (b) 24 April 2009, (c) 17 November 2009 and (d) 16 February 2010. The grey shaded area corresponds to the emersed condition

Table 2. Mean temperature during incubations $(T)$, primary producer biomass in the benthic chamber (PPB), and parameters estimated from the model of Webb et al. (1974): maximal gross community productivity $\left(\mathrm{GCP}_{\max }\right)$, saturation onset parameter $\left(I_{k}\right) . \mathrm{R}^{2}$ and p-values are presented for the fit of the Webb et al. model to each chamber under emersed conditions in the Zostera marina community in February 2010, March 2009, April 2008, June 2009, September 2008 and the Z. noltii community in January 2010, March 2009, April 2008, June 2008, June 2009, August 2008, September 2008 and November 2009. n: number of incubations

\begin{tabular}{|c|c|c|c|c|c|c|c|c|}
\hline Sampling date & $\begin{array}{c}T \\
\left({ }^{\circ} \mathrm{C}\right)\end{array}$ & $\begin{array}{c}\mathrm{PPB} \\
\left(\mathrm{g} \mathrm{C} \mathrm{m}^{-2}\right)\end{array}$ & $\begin{array}{c}\mathrm{CR} \\
\left(\mathrm{mg} \mathrm{C} \mathrm{m}^{-2} \mathrm{~h}^{-1}\right)\end{array}$ & $\begin{array}{c}\mathrm{GCP}_{\max } \\
\left(\mathrm{mg} \mathrm{C} \mathrm{m}^{-2} \mathrm{~h}^{-1}\right)\end{array}$ & $\begin{array}{c}I_{\mathrm{k}} \\
\left(\mu \mathrm{mol} \text { quanta } \mathrm{m}^{-2} \mathrm{~s}^{-1}\right)\end{array}$ & $\mathrm{n}$ & $\mathrm{R}^{2}$ & $\mathrm{p}$ \\
\hline \multicolumn{9}{|l|}{ Zostera marina } \\
\hline Feb 2010 & 7.7 & 56.34 & 16.92 & 42.65 & 91.79 & 7 & 0.915 & 0.002 \\
\hline Mar 2009 & 16.1 & 14.60 & 17.24 & 36.75 & 86.88 & 7 & 0.876 & $<0.001$ \\
\hline Apr 2008 & 7.9 & 18.17 & 15.93 & 24.75 & 90.74 & 6 & 0.966 & $<0.001$ \\
\hline Jun 2009 & 16.4 & 15.30 & 15.78 & 41.04 & 140.81 & 6 & 0.968 & $<0.001$ \\
\hline Sep 2008 & 15.8 & 63.51 & 57.54 & 141.63 & 124.37 & 7 & 0.995 & $<0.001$ \\
\hline \multicolumn{9}{|l|}{ Zostera noltii } \\
\hline Jan 2010 & 3.4 & 17.34 & 4.12 & 37.38 & 79.95 & 6 & 0.945 & $<0.001$ \\
\hline Mar 2009 & 9.9 & 8.85 & 9.32 & 47.28 & 129.32 & 7 & 0.998 & $<0.001$ \\
\hline Apr 2008 & 8.3 & 12.32 & 22.28 & 79.49 & 86.47 & 8 & 0.996 & $<0.001$ \\
\hline Jun 2008 & 14.4 & 24.41 & 20.98 & 62.91 & 201.89 & 9 & 0.922 & $<0.001$ \\
\hline Jun 2009 & 15.9 & 47.55 & 42.42 & 80.64 & 132.57 & 8 & 0.986 & $<0.001$ \\
\hline Aug 2008 & 19.6 & 87.11 & 51.39 & 115.43 & 204.45 & 8 & 0.973 & $<0.001$ \\
\hline Sep 2008 & 16.1 & 52.15 & 49.53 & 125.89 & 148.82 & 9 & 0.962 & $<0.001$ \\
\hline Nov 2009 & 14.6 & 18.92 & 8.75 & 47.23 & 128.29 & 6 & 0.983 & $<0.001$ \\
\hline
\end{tabular}




\section{DISCUSSION}

$\mathrm{CR}$ and GCP rates measured during immersion over the course of the year were within the range previously reported in the literature for both Zostera marina (Murray \& Wetzel 1987, Barranguet \& Alliot 1995, Martin et al. 2005) and Z. noltii communities (Vermaat \& Verhagen 1996, Viaroli et al. 1996, Plus et al. 2001). During emersion, CR and GCP rates were low but consistent with studies conducted on the same communities during 2008, when CR varied from 13.8 to $82.8 \mathrm{mg} \mathrm{C} \mathrm{m}^{-2} \mathrm{~h}^{-1}$ and GCP from 43.9 to $251.5 \mathrm{mg} \mathrm{C} \mathrm{m}^{-2} \mathrm{~h}^{-1}$ in the $Z$. marina community (authors' unpubl. data) and $\mathrm{CR}$ varied from 3.2 to $49.1 \mathrm{mg} \mathrm{C} \mathrm{m}^{-2} \mathrm{~h}^{-1}$ and GCP from 22.4 to $120.4 \mathrm{mg} \mathrm{C}$ $\mathrm{m}^{-2} \mathrm{~h}^{-1}$ in the $Z$. noltii community (Ouisse et al. 2010).

In the present study, immersion rates were significantly higher than emersion rates for both communities across different time periods. This main result confirms the observation made only once for a Zostera noltii community on the northwest coast of Mauritania (Clavier et al. 2011). More generally, a higher CR rate during immersion than emersion has been observed in previous studies of temperate mudflats (Gribsholt \& Kristensen 2003, Cook et al. 2004, Migné et al. 2009). In soft sediment, CR can be mainly ascribed to heterotrophic organisms (del Giorgio \& Williams 2005), and higher CR during immersion might be explained by enhanced bacterial and infaunal activity. This phenomenon might be amplified in seagrass beds, as bacterial metabolism in sediment and on seagrass leaves (Wittmann et al. 1981) is particularly enhanced due to the high organic matter inputs from plants (Holmer \& Nielsen 1997). In the present study, the GCP rate was much higher at the end of immersion than during emersion for both communities, whereas light intensity was always lower during immersion. This certainly cannot be explained by the contribution of planktonic organisms, which can be assumed to be negligible (see for example Santos et al. 2004, who measured a plankton contribution of approximately $0.01 \%$ to the metabolism of a $Z$. noltii community). Zostera spp. communities are also subjected to drastic $\mathrm{HCO}_{3}{ }^{-}$and $\mathrm{CO}_{2}$ concentration changes. Because of its high constant concentration in seawater, $\mathrm{HCO}_{3}{ }^{-}$is used directly or indirectly as a major source of inorganic carbon by Zostera spp. (Hellblom et al. 2001), whereas $\mathrm{CO}_{2}$ contributes only marginally to photosynthesis during immersion (Sand-Jensen \& Gordon 1984, Beer \& Rehnberg 1997). During emersion, the majority of carbon has to be supplied by atmospheric $\mathrm{CO}_{2}$ that passes through the thin water film remain-

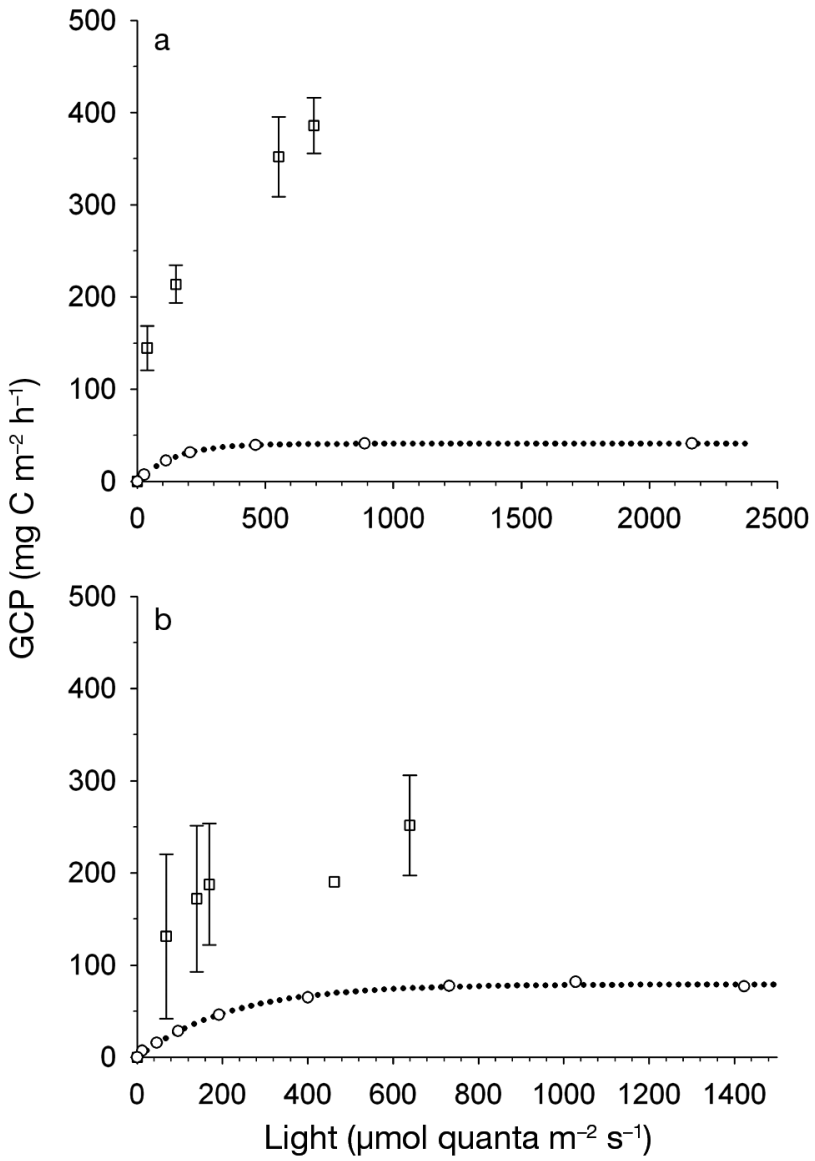

Fig. 4. Relationship between gross community productivity (GCP, $\mathrm{mg} \mathrm{C} \mathrm{m}^{-2} \mathrm{~h}^{-1}$ ) and irradiance ( $\mu \mathrm{mol}$ quanta $\mathrm{m}^{-2} \mathrm{~s}^{-1}$ ) in the (a) Zostera marina and (b) Z. noltii communities under emersed conditions in June 2009 and August 2008, respectively, according to the model of Webb et al. (1974) (open circles and dotted lines). Also shown is mean $( \pm \mathrm{SD})$ GCP under immersed conditions in July 2009 (open squares; see 'Materials and methods')

ing on the leaves (Leuschner \& Rees 1993). Considering the high affinity of plants to $\mathrm{CO}_{2}$ (see Touchette \& Burkholder 2007 for review) and the high availability of $\mathrm{CO}_{2}$ in the air, the seagrasses might not be limited by inorganic carbon needs during emersion. Measurements of photosynthesis versus irradiance during emersion for both communities highlighted the lack of a decrease in GCP under high irradiance (Fig. 4), and thus no photoinhibition. This is in accordance with previous studies on $Z$. marina (Mazzella \& Alberte 1986) and Z. noltii leaves (Jiménez et al. 1987); therefore, the low GCP observed during emersion cannot be ascribed to photoinhibition. During emersion, the leaves are flattened and only one side of the leaves can receive the incident light. In addition, the superimposition of leaves of the same shoot limits the exposure to light solely to external leaves. 
Finally, in the case of $Z$. marina, leaves cover the rest of the community and can decrease the incident light available to the other primary producers. Thus, the shading might have reduced GCP for both communities.

NCP decreased immediately at the beginning of emersion and did not vary throughout the air exposure period. Although the limitation of metabolism by desiccation has been described at the scale of both the plant (Björk et al. 1999) and the leaf (Shafer et al. 2007), the present study did not highlight any desiccation effect at the community scale. An important superficial cover of Zostera spp. kept the rest of the community moist and limited the evaporation from the sediment into the air.

At the annual scale, maximum underwater GCP rates for both communities varied with $\mathrm{PPB}$ (Table 1). However, the ratio between GCP and PPB for the Zostera marina community was lowest in summer. During this season, shading created by the superimposition of leaves in the small benthic chamber artificially reduced the light available for leaves and, as a consequence, decreased the GCP. The GCP:PPB ratio for $Z$. noltii community was highest in April. In winter and early spring, leaves did not grow much, allowing a high level of epiphyte colonization. In spring, epiphyte biomass was still high and the $Z$. noltii leaves started to grow. This could enhance the GCP at the community scale, as previously supposed based on results obtained for the same community during emersion (Ouisse et al. 2010).

In summary, the main explaination for the lower GCP during emersion than during immersion is the large effect of self-shading of the community by seagrass leaves. The leaf superimposition protected the community from high desiccation but decreased available light. No photoinhibition was demonstrated during emersion in either community. Even though there are clear Zostera noltii and $Z$. marina community distribution patterns in the intertidal zone, the present study did not find any clear difference in the metabolism responses to tidal cycle between these communities. This study highlights the importance of studying carbon fluxes at the community scale in order to take into account the complex interactions among species, especially as community-scale results sometimes contradict those obtained at the plant scale. In addition, tidal and seasonal variations need to be taken into account in order to estimate the role of Zostera spp. communities in the carbon cycle of the coastal zone.
Acknowledgements. This study forms part of the $\mathrm{PhD}$ thesis of V.O. and was financially supported by the 'Ministère de l'Enseignement Supérieur et de la Recherche'. The authors thank the Service Mer et Observation of the Station Biologique de Roscoff, A. Bonnefoy and S. Martin for their participation in field experiments and L. Noël and A. Cahill for editing and improving the English. They also thank the 3 anonymous referees, whose comments greatly contributed to the improvement of the manuscript.

\section{LITERATURE CITED}

Barranguet C, Alliot E (1995) Spatial and temporal variations of benthic fluxes (oxygen and ammonia) and microphytic biomass in a shellfish cultivation area of Thau Lagoon (France). J Rech Oceanogr 20:15-26

$>$ Beer S, Rehnberg J (1997) The acquisition of inorganic carbon by the seagrass Zostera marina. Aquat Bot 56: $277-283$

Björk M, Uku J, Weil A, Beer S (1999) Photosynthetic tolerances to desiccation of tropical intertidal seagrasses. Mar Ecol Prog Ser 191:121-126

Clavier J, Chauvaud L, Carlier A, Amice E and others (2011) Aerial and underwater carbon metabolism of a Zostera noltii seagrass bed in the Banc d'Arguin, Mauritania. Aquat Bot 95:24-30

> Cook PLM, Butler ECV, Eyre BD (2004) Carbon and nitrogen cycling on intertidal mudflats of a temperate Australian estuary. I. Benthic metabolism. Mar Ecol Prog Ser 280:25-38

$>$ de Jonge VN (1980) Fluctuation in the organic carbon to chlorophyll a ratios for estuarine benthic diatom populations. Mar Ecol Prog Ser 2:345-353

del Giorgio PA, Williams PJ (2005) Respiration in aquatic ecosystems. Oxford University Press, Oxford

> Drew EA (1979) Physiological aspects of primary production in seagrasses. Aquat Bot 7:139-150

Gribsholt B, Kristensen E (2003) Benthic metabolism and sulfur cycling along an inundation gradient in a tidal Spartina anglica salt march. Limnol Oceanogr 48: 2151-2162

> Hellblom F, Beer S, Björk M, Axelsson L (2001) A buffer sensitive inorganic carbon utilisation system in Zostera marina. Aquat Bot 69:55-62

Holmer M, Nielsen SL (1997) Sediment sulfur dynamics related to biomass-density patterns in Zostera marina (eelgrass) beds. Mar Ecol Prog Ser 146:163-171

Jeffrey SW, Humphrey GF (1975) New spectrophotometric equations for determining chlorophylls $a, b, c_{1}$ and $c_{2}$ in higher plants, algae and natural phytoplankton. Biochem Physiol Pflanz 167:191-194

> Jiménez C, Niell FX, Algarra P (1987) Photosynthetic adaptation of Zostera noltii Hornem. Aquat Bot 29:217-226

> Lee KS, Park SR, Kim YK (2007) Effects of irradiance, temperature, and nutrient on growth dynamics of seagrasses: a review. J Exp Mar Biol Ecol 350:144-175

> Leuschner C, Rees U (1993) $\mathrm{CO}_{2}$ gas exchange of two intertidal seagrass species, Zostera marina L. and Zostera noltii Hornem., during emersion. Aquat Bot 45:53-62

> Leuschner C, Landwehr S, Mehlig U (1998) Limitation of carbon assimilation of intertidal Zostera noltii and Zostera marina by desiccation at low tide. Aquat Bot 62: 171-176

> Martin S, Clavier J, Guarini JM, Chauvaud L and others 
(2005) Comparison of Zostera marina and maerl community metabolism. Aquat Bot 83:161-174

Mazzella L, Alberte RS (1986) Light adaptation and the role of autotrophic epiphytes in primary production of the temperate seagrass, Zostera marina L. J Exp Mar Biol Ecol 100:165-180

McRoy CP, McMillan C (1977) Production ecology and physiology of seagrasses. In: McRoy CP, Helfferich C (eds) Seagrass ecosystems: a scientific perspective. Dekker, New York, NY, p 53-81

Migné A, Davoult D, Spilmont N, Menu D, Boucher G, Gattuso JP, Rybarczyk H (2002) A closed-chamber $\mathrm{CO}_{2}$-flux method for estimating intertidal primary production and respiration under emersed conditions. Mar Biol 140: 865-869

Migné A, Spilmont N, Boucher G, Denis L and others (2009) Annual budget of benthic production in Mont SaintMichel Bay considering cloudiness, microphytobenthos migration, and variability of respiration rates with tidal conditions. Cont Shelf Res 29:2280-2285

Millero FJ, Zhang JZ, Lee K, Campbell DM (1993) Titration alkalinity of seawater. Mar Chem 44:153-165

Murray L, Wetzel RL (1987) Oxygen production and consumption associated with the major autotrophic components in two temperate seagrass communities. Mar Ecol Prog Ser 38:231-239

Nelder VA, Mead R (1965) A simplex method for function minimization. Comput J 7:308-313

Ouisse V, Migné A, Davoult D (2010) Seasonal variations of community production, respiration and biomass of different primary producers in an intertidal Zostera noltii bed (western English Channel, France). Hydrobiologia 649: $3-11$

Oviatt CA, Rudnick DT, Keller AA, Sampou PA, Almquist GT (1986) A comparison of system $\left(\mathrm{O}_{2}\right.$ and $\left.\mathrm{CO}_{2}\right)$ and C14 measurements of metabolism in estuarine mesocosms. Mar Ecol Prog Ser 28:57-67

Plus M, Deslous-Paoli JM, Auby I, Dagault F (2001) Factors

Editorial responsibility: William Kemp,

Maryland, USA influencing primary production of seagrass beds (Zostera noltii Hornem.) in the Thau Lagoon (French Mediterranean coast). J Exp Mar Biol Ecol 259:63-84

> Sand-Jensen K, Gordon DM (1984) Differential ability of marine and freshwater macrophytes to utilize $\mathrm{HCO}_{3}{ }^{-}$and $\mathrm{CO}_{2}$. Mar Biol 80:247-253

Santos R, Silva J, Alexandre A, Navarro N, Barrón C, Duarte C (2004) Ecosystem metabolism and carbon fluxes of a tidally-dominated coastal lagoon. Estuaries 27:977-985

> Shafer DJ, Sherman TD, Wyllie-Echeverria S (2007) Do desiccation tolerances control the vertical distribution of intertidal seagrasses? Aquat Bot 87:161-166

Silva J, Santos R, Calleja ML, Duarte CM (2005) Submerged versus air-exposed intertidal macrophyte productivity: from physiological to community-level assessments. J Exp Mar Biol Ecol 317:87-95

Strickland JDH, Parsons TR (1972) A practical handbook of seawater analysis. Bull Fish Res Board Can 167:1-311

Touchette BW, Burkholder JM (2007) Carbon and nitrogen metabolism in the seagrass, Zostera marina L.: environmental control of enzymes involved in carbon allocation and nitrogen assimilation. J Exp Mar Biol Ecol 350: 216-233

Vermaat JE, Verhagen FCA (1996) Seasonal variation in the intertidal seagrass Zostera noltii Hornem.: coupling demographic and physiological patterns. Aquat Bot 52: 259-281

> Viaroli P, Bartoli M, Bondavalli C, Christian RR, Giordani G, Naldi M (1996) Macrophyte communities and their impact on benthic fluxes of oxygen, sulphide and nutrients in shallow eutrophic environments. Hydrobiologia 329:105-119

- Webb WL, Newton M, Starr D (1974) Carbon dioxide exchange of Alnus rubra. Oecologia 17:281-291

Wittmann KL, Mazzella L, Fresi E (1981) Age specific patterns of leaf growth: their determination and importance for epiphytic colonization in Posidonia oceanica (L.) Delile. Rapp Comm Int Mer Medit 27:187-191

Submitted: July 14, 2010; Accepted: June 29, 2011 Proofs received from author(s): September 8, 2011 